\title{
Thomas Alan Kerr
}

\author{
Editor, Psychiatric Bulletin 1971-1998
}

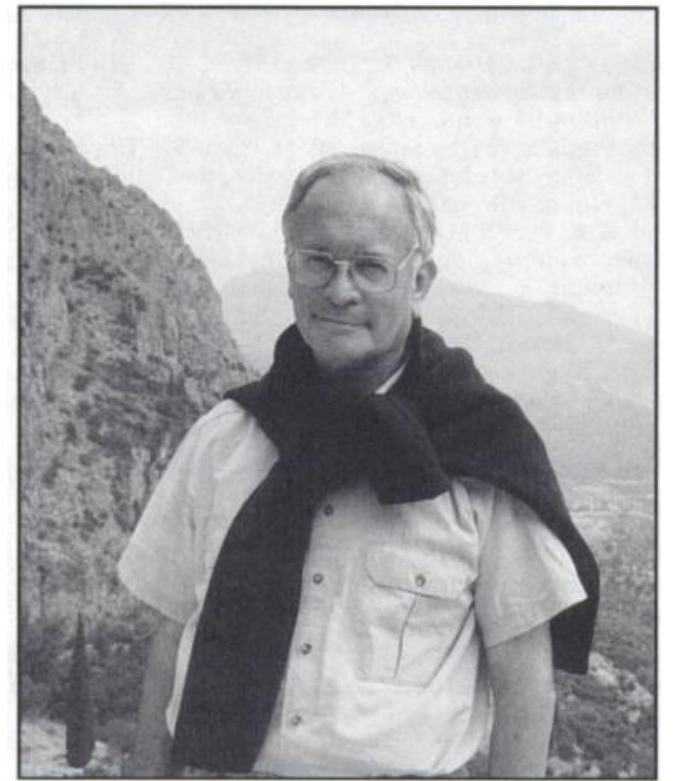

One way and another, I am deeply in hock to Alan Kerr. Nevertheless, I would have been pleased, nay delighted, to have sunk deeper into the red if only he had contrived to delay resigning the editorship of the Bulletin at least until the dawn of the millennium. In so doing he would have afforded me an opportunity of comparing like-with-like in terms of the momentousness of the two occasions.

Even so, Alan has already achieved more than enough to merit his inscription in the College's Hall of Fame, particularly in relation to his service to the British Journal of Psychiatry (BJP) and the Bulletin. Briefly, Alan was elected an Assistant Editor of the BJP in 1971, later to be promoted to Senior Associate Editor, and then, in August 1997, to Deputy Editor, the post he now holds. In his time he has the distinction of serving under no less than five editors, to wit. Eliot Slater (196172), Edward Hare (1973-77), John Crammer (1978-83), Hugh Freeman (1984-93) and now Greg Wilkinson (1993-). All in all, he has notched up 27 years of service, sufficient to rank him among such immortals as John Lord, G.W.T.H. Fleming and Alexander Walk, the last named having achieved an incredible record of 54 years' service to the BJP and its predecessor, the Journal of Mental Science.
Apart from the blood, sweat and tears that comes with the inky trade of editorship. Alan has proved himself to be an accomplished writer. Since 1972, he has displayed his widespread interests and expertise in his contributions to the BJP and the Bulletin either as a single author, or together with colleagues. His oeuvre is too long to list in full, and it would be invidious even to attempt to arrange them in some sort of rank order. Nevertheless, it would be a disservice to Alan not to mention a few of them. Almost at random I would pick out the Festschrift he edited in 1993 on the occasion of Hugh Freeman's retirement from the editorship of the BJP; and then his lengthy, unscripted interviews with famous (or infamous) persons including Thomas Szasz, Sir Bernard Tomlinson, Peter Kennedy and our President, Bob Kendell.

But Alan's lasting legacy will always be identified with the transformation he brought about in every aspect of the Bulletin. In 1983, when he took over the editorship, the Bulletin was a hotch-potch of "News and Notes", which was precisely its previous title. It was in truth nothing more than an inconsequential tail-piece to the BJP.

Today, the Bulletin has assumed the importance of a journal in its own right. It is carefully selected, well written into recognised sections, some of them serious and some of them determinedly light-hearted. There are some heretics, indeed (Tell it not in Gath, or in Belgrave Square) who maintain that today the tail is wagging the dog and that, not infrequently, the Bulletin is given priority over the BJP.

What future lies ahead for our Alan? I do not know, but I suspect that, with more time to spare, he will make every endeavour to improve his golf handicap before the zimmer is added to the equipment; and, further, I bet that he will spend more time in watching cricket until, that is, the England game is relegated to the village green.

But another thought comes to me: whereas the Editor of the BJP is allowed a statutory period of only 10 years in post, the Deputy Editor has no such restrictions. It follows, then, that, given a fair wind and a following tide, Alan is a hot favourite to be the first to beat the record Alexander Walk set so long ago.

Henry R. Rollin, Emeritus Consultant, West London Healthcare NHS Trust, Horton Hospital, Long Grove Road, Epsom, Surrey KT19 8PZ 